\title{
STRENGTHENING HEAT DAMAGED REINFORCED CONCRETE BEAMS USING GLASS FIBER-REINFORCED POLYMER (GFRP) LAMINATES
}

\author{
A.B. Danie Roy ${ }^{\mathrm{a}}$, Umesh K. Sharma ${ }^{\mathrm{b}}$, Pradeep Bhargava ${ }^{\mathrm{c}}$ \\ ${ }^{a}$ Indian Institute of Technology Roorkee, Research Associate Dept. of Civil Engineering Roorkee, India \\ ${ }^{\mathrm{b}}$ Indian Institute of Technology Roorkee, Associate Professor Dept. of Civil Engineering Roorkee, India \\ ${ }^{\mathrm{c}}$ Indian Institute of Technology Roorkee, Professor Dept. of Civil Engineering Roorkee, India
}

\begin{abstract}
A series of 21 reinforced concrete T- beams of length $1400 \mathrm{~mm}$ were cast using normal strength concrete. After 90 days of ageing, the beams were heated to $600^{\circ} \mathrm{C}$ and $900^{\circ} \mathrm{C}$ temperatures in an electric furnace. While three control beams were treated at room temperature, eighteen beams were heat damaged. The heat damaged beams were strengthened with FRP laminates and then tested until complete failure. Two different strengthening patterns of glass fiber reinforced polymer (GFRP) strengthening materials were used. The strengthened beams were then tested in a loading frame under 4 point loading condition. The load-deflection curves for the beams were examined to evaluate the capability of various strengthening patterns. Structural performance of various strengthening patterns were gauged in terms of failure mode, flexural strength, secant stiffness and the energy absorption capacity i.e. area under the load-displacement curve. It was observed that the beams exposed to different temperatures experienced a reduction in ultimate load carrying capacity ranging from $14 \%$ to $61 \%$. The secant stiffness and energy dissipation were reduced in the range of $34 \%$ to $56 \%$ and $10 \%$ to $41 \%$ respectively. The study shows that GFRP wraps were quite capable of restoring the flexural strength of heat damaged beams.
\end{abstract}

Keywords: Concrete beams, Heat Damage, Strengthening, Flexural Strength, Stiffness

\section{INTRODUCTION}

In today's built environment, the various civil engineering structures are liable to be exposed to fire or elevated temperature conditions. It has been observed that the structures, especially concrete structures, are generally not completely destroyed at such high temperatures. There is always a possibility for their restoration and rehabilitation after the heat exposure. Many researches have examined different aspects of concrete when exposed to high temperature (Anderberg et al. 1976). The aim of this research is to damage the reinforced concrete beam under various high temperatures and then strengthen the damaged element with different techniques.

Many experimental studies have been under taken in recent years to strengthen RC structures using suitable retrofitting and strengthening techniques. Strengthening pattern involves the use of materials other than that in original structure. Conventional materials for strengthening include Fiber Reinforced Polymer, Ferrocement, High Strength Fiber Reinforced Concrete, Steel plate bonding etc. Apart from low maintenance cost and improvement in the service life of buildings, Fibre Reinforced polymer (FRP) wrapping has several benefits e.g. high strength, light weight, resistance to corrosion, low cost, and versatility. Also the interaction between concrete and fiber enhances concrete strength and ultimate strain. Significant research have been undertaken on retrofitting the old concrete beams with FRP at room temperature conditions (Chajes et al. 1994, Gangarao et al. 1998, Saadatmanesh et al. 1998, Alagusuundaramoorthy et al. 2003, Esfahani et al. 2007 \& Ceroni 2010) but limited research has been reported on the repairing of fire damaged concrete elements (Bisby et al. 2011, Haddad et al. 2011, Yaqub et al. 2013 \& Roy et al. 2014). The main aim of this research is to investigate the effectiveness of applying GFRP jackets on heated damaged reinforced concrete beams; and to study the behavior of damaged and strengthened elements in terms of strength gain, ductility and failure modes. 


\section{EXPERIMENTAL PROGRAM}

An experimental programme was designed to examine the efficiency of GFRP techniques to restore the structural performance of heat damaged beams. A series of 21 reinforced concrete beams were constructed using normal strength concrete. The details of the specimens are illustrated in Table 1 and Fig. 1. Experimental variables included temperature of exposure and different pattern of strengthening. The concrete was prepared with crushed limestone aggregate of maximum size 12.5 $\mathrm{mm}$, ordinary Portland cement, natural river sand (zone 2), and portable water. The tension reinforcement consisted of 2 numbers of $12 \mathrm{~mm}$ diameter bars of $622.5 \mathrm{MPa}$ yield strength, compression reinforcement of 4 numbers of $8 \mathrm{~mm}$ diameter of $650 \mathrm{MPa}$ yield strength, while 580 $\mathrm{MPa}$ of reinforcing steel with a diameter of $6 \mathrm{~mm}$ were used as stirrup reinforcement. The spacing of stirrup used was $100 \mathrm{~mm}$ as shown in Fig. 1. All the beams were of same cross-section and length. The quantities of all materials were kept ready in required proportion to cast a beam at a time from one batch of concrete with three cubes, prisms and cylinders in order to monitor the strength at the time of testing. A concrete cover of $15 \mathrm{~mm}$ was provided in all the T-beams. Six $\mathrm{K}$ type thermocouples were placed in each beam during casting in order to monitor the temperature at the time of heating. Three $\mathrm{K}$ type thermocouples were placed at the center of the web and the other was attached to flange area. The specimens were cast using steel moulds in the laboratory. Needle vibrator was used during the casting of T- beams. After $24 \mathrm{hrs}$, the beams were removed from the moulds and covered with gunny bags for curing. The water curing period lasted for 28 days after which the beams were kept in the laboratory at ambient temperature and humidity conditions for another 120 days.

Table 1 Details of beam specimens

\begin{tabular}{|c|c|c|}
\hline Beam designation & Beam condition & Strengthening methods \\
\hline TBA & Control & none \\
\hline TB6 & Heat damaged $600^{\circ} \mathrm{C}$ & none \\
\hline TB9 & Heat damaged $900^{\circ} \mathrm{C}$ & none \\
\hline TB6 GFRP/U & Heat damaged $600^{\circ} \mathrm{C}$ & GFRP/U-Wrap \\
\cline { 1 - 1 } TB6 GFRP & & GFRP/Flexural \& shear region \\
\hline TB9 GFRP/U & Heat damaged $900^{\circ} \mathrm{C}$ & GFRP/ U-Wrap \\
\cline { 1 - 1 } & & GFRP/Flexural \& shear region \\
\hline
\end{tabular}
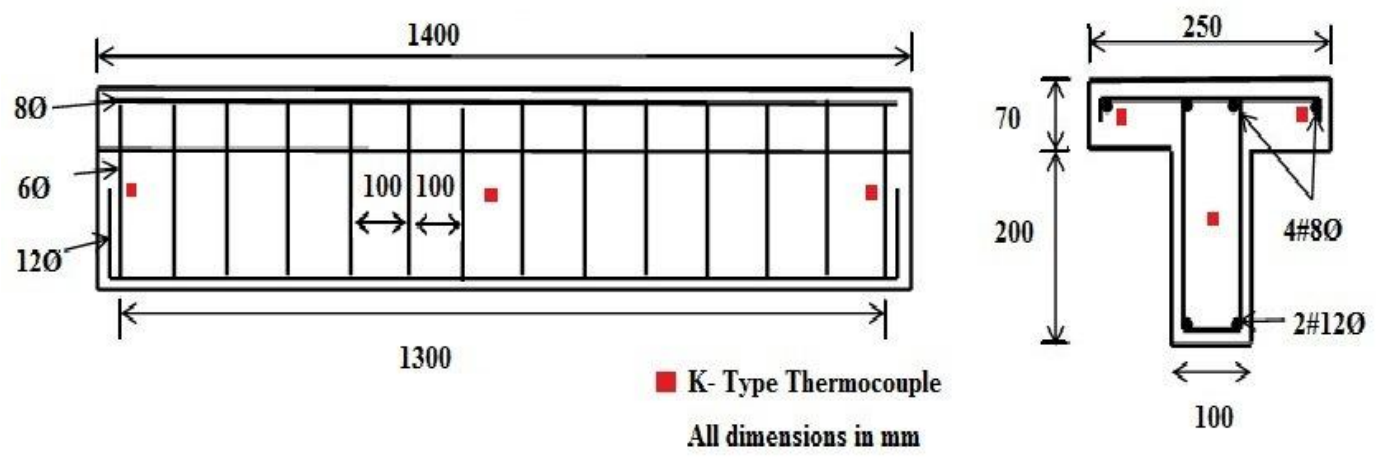

Fig. 1 Reinforcement details of T- Beam

\subsection{Thermal Testing}

Beam specimens were subjected to heat treatment using table mounted electrical furnace. The programmable electrical furnace with a maximum heating temperature of $1200^{\circ} \mathrm{C}$ was used for 
heating the specimens. The temperature inside the furnace was measured with K-type thermocouples. The beams were exposed to two different target temperatures $600^{\circ} \mathrm{C}$ and $900^{\circ} \mathrm{C}$ after 150 days. The furnace was able to accommodate one beam at a time. The $\mathrm{T}$ - beam specimen was placed in the furnace upside down so that the top face of the flange remains unexposed, which resembles the real condition of the roof beams in a building. The heating rate was set at $10^{\circ} \mathrm{C} / \mathrm{min}$, which has been shown to be reasonable for structures exposed to fire. Each target temperature was maintained for three hours to achieve a thermal steady state condition as shown in Fig. 2 . The heating rate of $10^{\circ} \mathrm{C} /$ minute means the rate of temperature rise inside the furnace, and not the rise of temperature inside the concrete specimens.

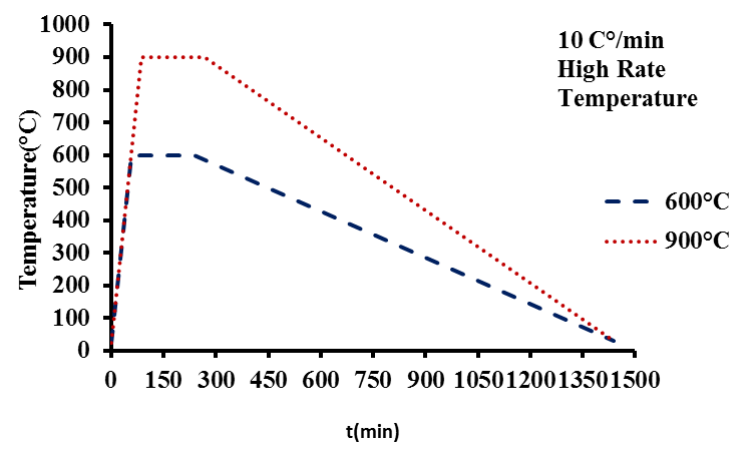

Fig. 2 Heating and cooling cycle

\subsection{Observation after heating}

When evaluating the condition of damaged beams, visible damage and the results of visual inspection are used to identify damage and assess its magnitude at the first instance. Visible damage can be such as cracks, spalled areas, colour change etc. In this study the colour of concrete changed to light greyish at $600^{\circ} \mathrm{C}$. However, the colour of specimens changed to ash white when exposed to $900^{\circ} \mathrm{C}$. The colour change may be attributed to the changes in the chemical composition of cementing materials and aggregates. The observations of colour change due to the heating and cooling of concrete also gives an idea of the degree of temperatures reached. In the heated test specimens some hairline cracks were observed at $600^{\circ} \mathrm{C}$. The number of cracks became relatively pronounced at $900^{\circ} \mathrm{C}$. Due to high temperature especially at $900^{\circ} \mathrm{C}$, the concrete suffered extensive cracking.

\subsection{Strengthening of heat damaged specimen}

After heat exposure, the heat damaged beams which got cracked and crumbled, were repaired before further strengthening. The cracked section was removed and restored using micro-concrete. Then the surface of specimen was cleaned thoroughly by water and then by compressed air to ensure no dust. A primer coat of bonding agent was applied on the resulting surface of the specimen to achieve good bonding between the old concrete and new repair material i.e. micro concrete The epoxy resins were prepared by mixing two components (resin and hardener components) strictly following the manufacturer's instructions. Once the bond coat became tacky, the micro concrete was applied to the specimens. The micro concrete repaired beams were covered with damp gunny bags for 7 days and kept in laboratory conditions until strengthening. The specimens, which did not undergo any damage, were directly strengthened. The surface projection and corners of the beams were rounded off slightly to ensure that the strengthening materials were not damaged due to stress concentration at the corners of the beam specimens. The surface prepared and heat damaged beams were further strengthened by various patterns of GFRP (Fig. 3). Before GFRP jacketing the surface of heat damaged specimens were scraped lightly to remove surface contaminants. Then the surface of the concrete was coated with a layer of epoxy primer on the external surfaces of the concrete to fill air voids and to provide good bond strength. Thereafter, a thin layer of the two part saturant solution consisting of resin and hardener mixed as per the manufacturer's specifications was applied over the web at bottom and side of web on both sides of shear regions. Then the first layer of GFRP 
sheets was wrapped on the bottom of the web carefully. A roller was used to remove the entrapped air between the fiber and excess saturant so as to allow better impregnation of the saturant. Special attention was taken to ensure that no air voids were left between the fiber and the concrete surface. After the application of the first wrap, a second layer of saturant solution was applied on the surface of the first layer in length. The roller was used again to remove any trapped air and to force the resin in the fibers (Fig. 4). All the specimens were stored at room temperature for at least 28 days before testing.
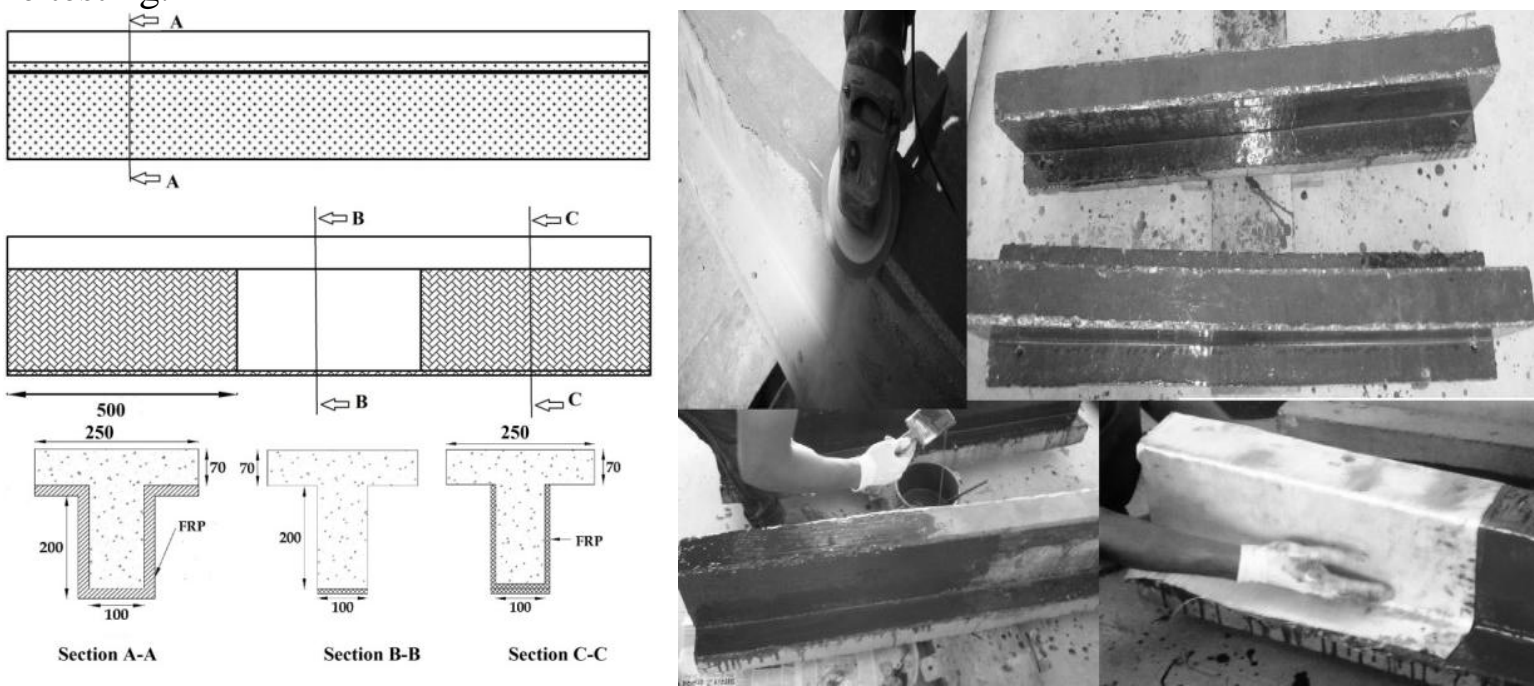

Fig. 3 Strengthening pattern

Fig. 4 GFRP jacketing

\section{INSTRUMENTATION AND TEST SETUP}

Mechanical testing of the specimens was carried out after a complete cycle of heating, cooling and then strengthening. The test beams were loaded using a 200 Ton capacity hydraulically hand operated jacks connected to a data acquisition system through load cells. The beams were tested under monotonic increasing load. The deflection of the beam was noted using linear variable differential transducer (LVDT), placed at five locations at the bottom of beams connected to data logger as shown in Fig.5. The strain gauges were mounted on bottom of web and side of web in GFRP jacketing. The recorded data from the LVDTs, strain gauges and load cell were fed into a data acquisition system and stored on a computer.

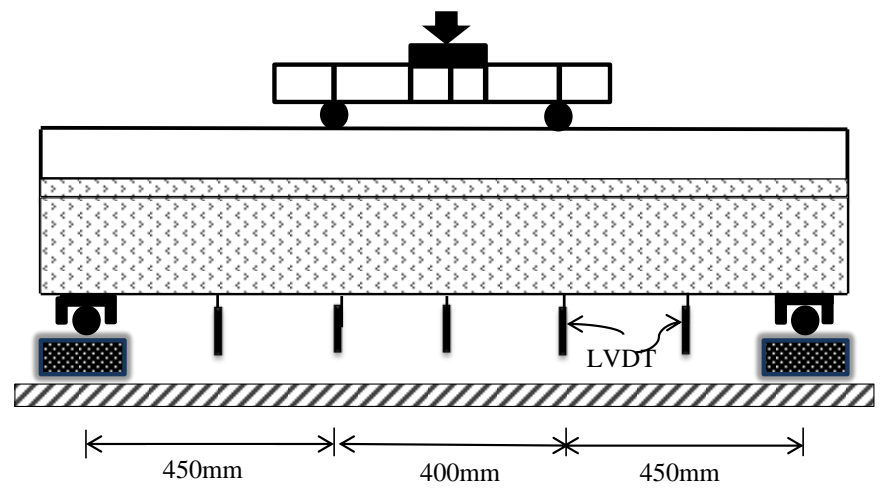

Fig. 5: Test setup

\section{TEST RESULTS AND DISCUSSION}

The performances of beams were assessed through the load deflection curves Figs. 6 and results are summarized in Table 2.The yield load Py was the applied load at which the beam starts to yield and $\mathrm{Pu}$ was the ultimate load measured on each beam. The $\mu \Delta$ is the deflection ductility index and $\Delta \mathrm{y}$ and $\Delta \mathrm{u}$ are the mid span deflection at yield load and ultimate load of the beam respectively. 


\subsection{Failure modes of Control specimen, Heat damaged beams and Strengthened beams}

The overall behavior of reinforced concrete undamaged beam and heat damaged beam were assessed by studying the load-deflection diagram. The results of the beam are summarized in Table 2 and Fig 6. The ultimate strength of all heat damaged beams was lesser when compared with undamaged beams. The undamaged beam failed at $195 \mathrm{kN}$, whereas the heat damaged $600 \mathrm{oC}$ and $900^{\circ} \mathrm{C}$ failed at 166 and $76 \mathrm{kN}$ respectively. The decrease in ultimate load was steeper beyond $600^{\circ} \mathrm{C}$. When the undamaged beams were loaded in the laboratory they developed flexural tensile crack in the hinge region at an average load of $43 \mathrm{kN}$. Around $153 \mathrm{kN}$, the beam started to yield and the beam finally failed in flexure at a load of $195 \mathrm{kN}$. Similarly in $600^{\circ} \mathrm{C}$ heat damaged beam first crack load was at $26 \mathrm{kN}$ and flexural crack develop in the mid- span region and cracks were initiated in shear span region but finally failed in flexure at a load of $166 \mathrm{kN}$. Also $900^{\circ} \mathrm{C}$ heat damaged beam the first crack load was $21 \mathrm{kN}$ shows significant decrease in first crack load as compared to undamaged beam.

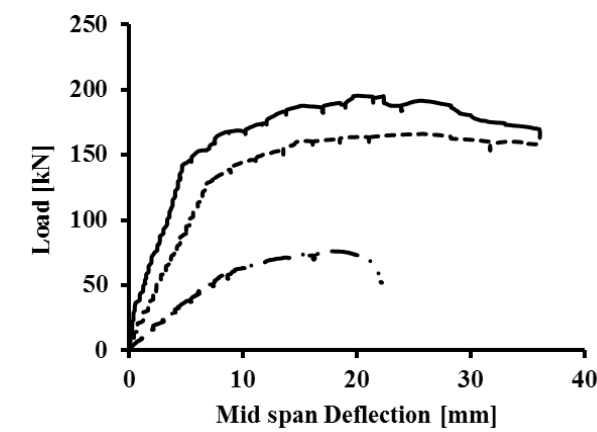

(a)

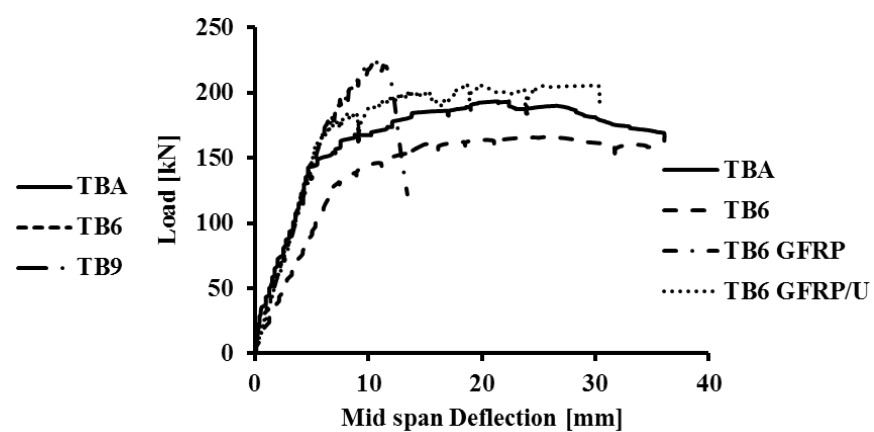

(b)

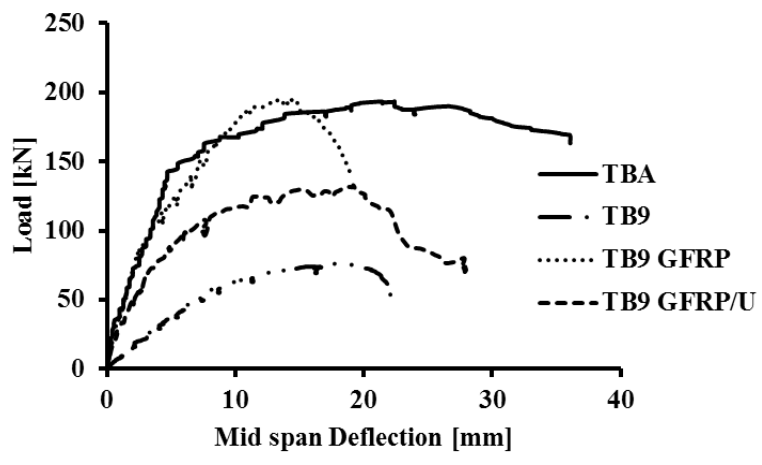

(c)

Fig. 6 Load-deflection relationship of control, heat-damaged and strengthened beams

The load deflection behavior of the strengthen heat damaged beam with different strengthening patterns are shown in Fig 6 b-c. Figure $6 \mathrm{~b}$-c shows the load deflection behavior of $600^{\circ} \mathrm{C}$ and $900^{\circ} \mathrm{C}$ heat damaged strengthened beam with GFRP jacketing. The both strengthening pattern improves the ultimate load capacity of $600^{\circ} \mathrm{C}$ heat damaged beams, no strength gain was observed in case of $900^{\circ} \mathrm{C}$ heat damaged beam when strengthen with $\mathrm{U}$-wrap compared to undamaged beams. The $600^{\circ} \mathrm{C}$ heat damaged beam strengthened with GFRP and GFRP/U took $15 \%, 6 \%$ more ultimate load when compared to undamaged beam respectively, 35\%, $21 \%$ respectively when compared with that of heat damaged ones. $900^{\circ} \mathrm{C}$ heat damaged beams strengthened with GFRP and GFRP/U shows increase and reduction in ultimate load carrying capacity by $+1 \%,-32 \%$ respectively of that of undamaged beams. TB6 GFRP/U and TB9 GFRP/U beams have higher deflection ductility and energy ductility when compared with TB6 GFRP and TB9 GFRP strengthening. 
Table 2 Summary of beam test results

\begin{tabular}{|c|c|c|c|c|c|c|c|c|c|}
\hline \multirow[t]{2}{*}{$\begin{array}{l}\text { T-Beam } \\
\text { Designation }\end{array}$} & \multicolumn{2}{|c|}{ Load $(\mathrm{kN})$} & \multicolumn{2}{|c|}{ Deflection } & \multirow{2}{*}{$\begin{array}{l}\text { Deflection } \\
\text { Ductility } \\
\text { Factor } \\
\mu_{\Delta}=\Delta \mathrm{u} / \Delta \mathrm{y}\end{array}$} & \multicolumn{2}{|c|}{ Energy } & \multirow{2}{*}{$\begin{array}{l}\text { Energy } \\
\text { Ductility } \\
\text { Factor } \\
\mu_{\mathrm{E}}=\mathrm{E}_{\mu} \mathrm{E}_{\mathrm{y}}\end{array}$} & \multirow[t]{2}{*}{ Failure Mode } \\
\hline & $\begin{array}{l}\text { Yield Load } \\
\mathrm{P}_{\mathrm{y}}(\mathrm{kN})\end{array}$ & $\begin{array}{l}\text { Ultimate Load } \\
\mathrm{P}_{\mathrm{u}(\mathrm{kN})}\end{array}$ & $\Delta \mathrm{y}(\mathrm{mm})$ & $\Delta \mathrm{u}(\mathrm{mm})$ & & $\begin{array}{l}\mathrm{E}_{\mathrm{YX}} \\
(\mathrm{kN} \cdot \mathrm{mm})\end{array}$ & $\begin{array}{l}\mathrm{E}_{\mathrm{y}} \\
(\mathrm{kN} . \mathrm{mm})\end{array}$ & & \\
\hline TBA & 153 & 195.36 & 6.84 & 20.01 & 2.925 & 1457 & 4292 & 2.944 & Flexural \\
\hline TB6 & 141 & 166.00 & 9.13 & 25.77 & 2.822 & 1031 & 3859 & 3.740 & Flexural \\
\hline TB9 & 60 & 76.09 & 9.03 & 17.86 & 1.977 & 1096 & 2269 & 2.070 & $\begin{array}{l}\text { Shear failure at } \\
\text { support }\end{array}$ \\
\hline TB6 GFRP/U & 195 & 207.37 & 6.4 & 18.58 & 2.903 & 1594 & 5315 & 3.3 & Flexural \\
\hline TB6 GFRP & 194 & 225.90 & 7.48 & 10.89 & 1.455 & 1205 & 2121 & 1.760 & $\begin{array}{l}\text { Flexural failure } \\
\text { and debonding of } \\
\text { shear fabric }\end{array}$ \\
\hline TB9 GFRP/U & 122 & 132.88 & 6.01 & 19.14 & 3.18 & 449 & 2294 & 5.01 & Flexural \\
\hline TB9 GFRP & 140 & 195.91 & 6.99 & 14.29 & 2.044 & 1103 & 2428 & 2.201 & $\begin{array}{l}\text { Debonding of } \\
\text { fabric in shear } \\
\text { region }\end{array}$ \\
\hline
\end{tabular}

\section{CONCLUSIONS}

The performance of heat damaged reinforced concrete beams strengthened with GFRP techniques subjected to different strengthening schemes are presented in this paper. Based on the observations and experimental results following conclusion are made:

1. In reinforced concrete exposed to different temperature ultimate load carrying capacity was affected by about $14 \%, 61 \%$ respectively when compared with undamaged beams.

2. TB6 GFRP and TB6 GFRP/U techniques improves the ultimate load capacity of $600^{\circ} \mathrm{C}$ heat damaged beams, strength achieved in case of $900^{\circ} \mathrm{C}$ heat damaged beam was lesser when compared to undamaged beams.

3. The beam heat damaged at $600^{\circ} \mathrm{C}$ and $900^{\circ} \mathrm{C}$ showed less ductility when compared with undamaged beams of about $4 \%$ and $32 \%$ respectively. The TB6 GFRP/U and TB9 GFRP/U strength beam were more ductile when compared with undamaged beams,TB6 GFRP and TB9 GFRP.

5. The load corresponding to concrete cracking increased considerably when the damaged beams are strengthened with different strengthening patterns.

\section{REFERENCES}

Alagusuundaramoorthy P., Harik I.E., Choo C.C. 2003. Flexural behaviour of RC beams strengthened with carbon fibre reinforced polymer sheets or fabric. Journal of Composites for Construction, 7(4), 292-301.

Anderberg Y., Thelandersso S.1976. Stress and deformation characteristics of concrete at high temperatures, Lund Institute of Technology, Lund, Sweden

Bisby L.A., Chen J.F., Li S.Q., Stratford T.J., Cueva N., Crossling K. 2011. Strengthening fire-damaged concrete by confinement with fibre-reinforced polymer wraps. Engineering Structures, 33, 3381-3391.

Ceroni F. 2010. Experimental performances of RC beams strengthened with FRP Material. Construction and Building Materials, 24, 1547-1559.

Chajes M J., Thomson T., Finch W W., Januszka T. 1994. Flexural strengthening of concrete beams using externally bonded composite materials. Construction and Building Materials, 8(3), 191-201.

Danie Roy A.B., Sharma U.K., and Bhargava P. 2014. Strengthening of heat damaged reinforced concrete short columns. Journal Structural Fire Engineering, 5 (4), 381-398

Esfahani M R., Kianoush M R., Tajari A R. (2007). Flexural behavior of reinforced concrete beams strengthened by CFRP sheets. Engineering Structures, 29(10), 2428-2444.

Gangarao H V S., Vijay P V. 1998. Bending behavior of concrete beams wrapped with carbon fabric. Journal of Structural Engineering-ASCE, 124(1), 03-10.

Haddad R.H, Shannag M.J., Hamad R.J. 2011. Repair of heat-damaged reinforced concrete T-beams using FRC jackets. Magazine of Concrete Research, 59 (3), 223-231.

Saadatmanesh H., Malek A M. 1998. Design guidelines for flexural strengthening of RC beams with FRP plates. Journal of CompositesConstruction, 2(4), 158-164.

Yaqub M., Bailey C.G., Nedwell P., Khan Q.U.Z., Javed I. 2013. Strength and stiffness of post-heated columns repaired with ferrocement and fibre reinforced polymer jackets. Composites: Part B. 44, 200-211. 